\title{
Poligame Nylkrokodille (Crocodylus niloticus) op'n krokodilplaas: Vrugvliese vertel die storie
}

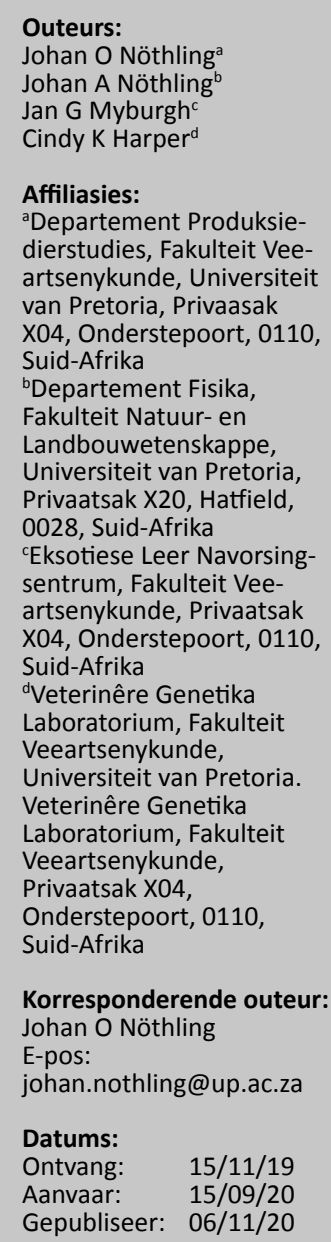

\section{Affiliasies:}

${ }^{a}$ Departement Produksiedierstudies, Fakulteit Veeartsenykunde, Universiteit van Pretoria, Privaasak X04, Onderstepoort, 0110, Suid-Afrika

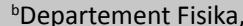
Fakulteit Natuur- en Landbouwetenskappe, Universiteit van Pretoria, Privaatsak X20, Hatfield, 0028, Suid-Afrika

'Eksotiese Leer Navorsingsentrum, Fakulteit Veeartsenykunde, Privaatsak X04, Onderstepoort, 0110 Suid-Afrika

'Veterinêre Genetika Laboratorium, Fakulteit Veeartsenykunde, Universiteit van Pretoria. Veterinêre Genetika Laboratorium, Fakulteit Veeartsenykunde,

Privaatsak X04, Onderstepoort, 0110, Suid-Afrika

Korresponderende outeur: Johan O Nöthling

E-pos:

johan.nothling@up.ac.za

Datums:

Ontvang: $\quad 15 / 11 / 19$

Aanvaar: $\quad 15 / 09 / 20$

Gepubliseer: 06/11/20

Hoe om hierdie artikel aan te haal:

Johan O Nöthling, Johan A Nöthling, Jan G Myburgh, Cindy K Harper,

Poligame Nylkrokodille

(Crocodylus niloticus) op'n krokodilplaas: Vrugvliese vertel die storie, SuidAfrikaanse Tydskrif vir Natuurwetenskap en Tegnologie 39(1) (2020). https://doi.org/10.36303/ SATNT.2020.39.1.750

An English copy of this paper is available online at http://www.satnt.ac.za/ index.php/satnt/article/ view/750

\section{Kopiereg:}

(C) 2020. Authors

Licensee: Die Suid-

Afrikaanse Akademie vir

Wetenskap en Kuns.

Hierdie werk is onder

die Creative Commons

Attribution License

gelisensieer.
Meer as een vaar in 'n krokodilbroeisel verhoog die effektiewe populasiegrootte en lei tot 'n stadiger verlies van genetiese variasie as gevolg van inteling en lukraak genetiese swerwing. Meer as een vaar kan ook die variasie met betrekking tot eienskappe wat van kommersiële belang is tussen krokodille uit dieselfde broeisel verklaar. Vrugvliese kan 'n nie-ingrypende bron van DNS verskaf waarmee die genotipe van Nylkrokodilbroeilinge (Crocodylus niloticus) bepaal kan word. Die doel van hierdie studie was om vas te stel hoe doeltreffend die genotipe van Nylkrokodilbroeilinge uit die vrugvliese wat in uitgebroeide eiers agterbly bepaal kan word en of ' $n$ broeisel uit 'n kommunale teeldam op 'n kommersiële plaas meer as een vaar kan hê. Elf mikrosatellietloki is gebruik om die DNS-profiele van 4-6 (gemiddeld 4.4) vrugvliesmonsters (VVMe) van elk van 25 broeisels uit dieselfde teeldam op 'n kommersiële Nylkrokodilplaas te bepaal. DNS het op al 11 loki in 95 van die 110 individue vermeerder, op 1-10 loki in 13 en op geen lokus nie in twee. Drie tot 20 allele is per lokus gevind. Afsonderlike beoordeling van loki het getoon dat 13 broeisels minstens twee vaars gehad het. Met ' $n$ multilokusprogram (Colony) is afgelei dat 19 broeisels minstens twee vaars gehad het, en dat poliandrie en poliginie algemeen was. Verdere navorsing is nodig om die nuttigheid van vrugvliese as ' $n$ bron van DNS vir nesse uit die natuur te bepaal en om, deur meer VVMe per broeisel te gebruik, die mate van poliandrie en poliginie op Nylkrokodilplase en in die natuur meer presies te bepaal.

Sleutelwoorde: Krokodille, eier, broeiling, vrugvliese, DNS, vaar.

Polygamous farmed Nile crocodiles (Crocodylus niloticus): Foetal membranes tell the story: Multiple paternity in crocodilian broods would increase effective population size and slow down the loss of genetic variation due to inbreeding and random genetic drift in real populations. Multiple paternity may also explain variation among offspring of the same brood with respect to characteristics of commercial interest to crocodile farmers. Foetal membranes may provide a non-invasive source of DNA from which to determine the genotypes of Nile crocodile (Crocodylus niloticus) hatchlings. The aims of this study were to determine the effectiveness of using the foetal membranes remaining inside the hatched eggs to determine the genotypes of Nile crocodile hatchlings, and to determine whether a brood (the hatchlings from a clutch of eggs) from a communal breeding pond on a commercial farm may have more than one sire. DNA profiles were determined on 4-6 (mean 4.4) foetal membrane specimens (FMSs) from each of 25 broods from the same breeding pond on a commercial Nile crocodile farm. Eleven microsatellite loci were used. DNA amplification occurred at all 11 loci in 95 of the 110 genotyped individuals, at 1-10 loci in 13 and at no locus in two. Three to 20 alleles were found per locus. Single-locus assessment showed that 13 broods had at least two sires. A multilocus programme (Colony) inferred that 19 broods had at least two sires, with polyandry and polygyny being common. Further research is necessary to determine the utility of foetal membranes as a source of DNA from nests in the wild and, using more FMSs per brood, to more precisely determine the extent of polyandry and polygyny in farmed and wild Nile crocodiles.

Keywords: crocodile, egg, hatchling, foetal membrane, DNA, sire 


\section{Inleiding}

'n Nylkrokodilwyfie (Crocodylus niloticus) lê een broeisel eiers per jaar gedurende die lente of vroegsomer (Huchzermeyer, 2003), alhoewel sy in sommige jare nie lê nie. 'n Nylkrokodilwyfie lê 'n variërende aantal eiers (gemiddeld 40) (Khosa et al., 2012) in 'n enkele gat (nes) wat sy naby die water in sanderige grond grawe (Kofron, 1989). Sodra sy al haar eiers gelê het bedek sy die nes met grond (Kofron, 1989). Wanneer die eiers omtrent drie maande later uitbroei (Hutton, 1987) krap die wyfie die nes oop, versamel die broed (al die broeilinge uit die broeisel) en laat hulle in die water vry (Combrink et al., 2016). Op kommersiële plase grawe werkers die nes so gou as moontlik nadat die eiers gelê is oop en verwyder die eiers. Die eiers word dan horisontaal, langs mekaar in een of, in die geval van groot broeisels, twee polistireenkiste geplaas. Die kiste word met deksels toegemaak en geïnkubeer totdat die eiers uitbroei.

Wanneer 'n Nylkrokodilfetus uitbroei, breek dit deur die dopmembraan en die dop by een pool van die eier (Nöthling et al., 2019a) en verlaat die eier, terwyl die vrugvliese in die dop agterbly.

In bevrugte krokodileiers neem die vrugvliese-die chorion, allantois, amnion en die dooiersak - hul oorsprong deur mitose uit die sigoot (McGeady et al., 2017). Die vrugvliese het dus dieselfde genotipe as die embrio en, uiteindelik, die broeiling wat uit die eier voortkom. Vrugvliese wat in die eierdop agterbly is dus 'n potensiële bron van DNS waarmee die genotipe van broeilinge op nieingrypende wyse bepaal kan word. Vrugvliese is nog nie gebruik om die genotipe van krokodilbroeilinge mee te bepaal nie.

Die eiers in ' $n$ kis broei dikwels kort na mekaar uit. Sodra hulle uitbroei kruip die broeilinge in die kis rond en kontamineer moontlik die buitenste oppervlak van ander eiers met hul DNS.

Mits die vrugvliese in die eierdoppe ongekontamineer bly kan hulle versamel word nadat al die broeilinge uit die kis verwyder is en gebruik word om die broeilinge se genotipes te bepaal.

Broeisels met meer as een vaar (meervaarbroeisels) is oor die algemeen voordelig. Dit verhoog die effektiewe populasiegrootte (Sugg en Chesser, 1994) en vertraag sodoende die verlies van genetiese variasie as gevolg van genetiese swerwing (Hartl, 2000). 'n Wyfie waarvan die broed meer as een vaar het, het ' $n$ voordeel omdat haar broed waarskynlik meer aanpasbaar sal wees by 'n verskeidenheid habitatte (Davis et al., 2001). Meervaarbroeisels kan van spesifieke belang vir krokodilboere wees. Nöthling et al. (2019b) het getoon dat, vir 'n bepaalde eiergrootte, broeilingmassa binne Nylkrokodilbroeisels varieer. Dit is van belang om te weet of hierdie variasie binne broeisels die gevolg is van genetiese verskille wat deur verskillende vaars meegebring word. Dieselfde geld vir ander eienskappe wat binne broeisels varieer en wat vir krokodilboere van kommersiële belang is.

Meervaarbroeisels kom voor in die Amerikaanse alligator (Alligator mississippiensis) (Davis et al., 2001; Lance et al., 2009), die breësnoet kaaiman (Caiman latirostris) (Amavet et al., 2008), Morelet se krokodil (Crocodylus moreletii) (McVay et al., 2008), die Orinocokrokodil (Crocodylus intermedius) (Lafferriere et al, 2016) en die swart kaaiman (Melanosuchus niger) (Muniz et al., 2001). Meervaarbroeisels is nog nie in die Nylkrokodil beskryf nie.

Miesfeld et al. het reeds in 1987 'n blok 17 TG dinukleotiede in 'n gebied tussen die $\delta$ en $\beta$ globiengene van die mens beskryf wat ook deur die hele menslike genoom voorkom. 'n Paar jaar later het Litt en Luty (1989) PKR gebruik om 'n hipervarieerbare (TG)n mikrosatelliet in die menslike aktiengeen te identifiseer, en getoon dat dit deur kodominante mendeliese oorerwing oorgeërf word. Litt en Luty het die potensiaal gesien om genetiese skakeling met mikrosatelliete te bestudeer. Rassmann et al. (1991) beskryf die gebruik van flank aanvangskodes (flanking primers) en PKR om mikrosatelliete van enige eukariotiese DNS te isoleer en vir DNS vingerafdrukke te gebruik. Schlötterer and Tautz (1992) het bevind dat die hoë mate van polimorfisme in mikrosatelliete die gevolg is van mutering wat plaasvind wanneer DNS tydens replisering glip. Volgens Fitzsimmons et al. (2000) is mikrosatelliete nie so algemeen in krokodille as in ander taksons nie. Tóg het Miles et al. (2009) 82 mikrosatelliete wat voorheen in die soutwaterkrokodil (C. porosus) geïsoleer is ondersoek om te bepaal of hulle in 18 ander krokodilsoorte, waaronder $C$. niloticus, vermenigvuldig. Die 82 mikrosatelliete is ná aftasting van die hele genoom uit 253 kort tandem herhalings (enkelvoud KTH, meervoud KTHs) gekies op grond van hul betreklik eweredige verspreiding deur die genoom en hoë polimorfe inligtingsinhoud in C. porosus. $\mathrm{Al}$ 11 loki wat in die huidige studie gebruik is was onder die 82 wat Miles et al. beoordeel het en bevestig het dat elkeen 5-9 allele in agt Nylkrokodilmonsters geïdentifiseer het.

Die doelwitte van hierdie studie op Nylkrokodille was om vas te stel of die vrugvliese uit eiers wat onlangs uitgebroei het DNS verskaf wat doeltreffend vermenigvuldig en of die broeisels uit 'n kommunale teeldam op 'n kommersiële krokodilplaas meer as een vaar mag hê.

\section{Materiale en metodes}

\section{Die neem en merk van monsters}

Die monsters is gedurende Januarie 2013 tydens 'n enkele teelseisoen van die enigste teeldam op 'n kommersiële Nylkrokodilplaas versamel. Le Croc Estate lê $19 \mathrm{~km}$ noordwes van Brits in die Noordwes provinsie in SuidAfrika ( $25^{\circ} 29^{\prime} 37^{\prime \prime} \mathrm{S}, 27^{\circ} 40^{\prime} 50^{\prime \prime} \mathrm{O}$, hoogte $1028 \mathrm{~m}$ ). Die teeldam was nagenoeg reghoekig, $100 \mathrm{~m} \times 57 \mathrm{~m}$ met 'n oppervlakte van omtrent $5650 \mathrm{~m}^{2}$ en 'n sonbakstrook van omtrent $5 \mathrm{~m}$ wyd rondom die dam. Daaromheen was omtrent 180 nesmaakgebiede van $4 \mathrm{~m} \times 1.8 \mathrm{~m}$ wat elk op 
drie grense met ' $n$ steenmuur omring is, met die oop kant na die water gerig. Daar was ook 'n sanderinge nesmaakgebied van omtrent $2050 \mathrm{~m}^{2}$ suidwes van die dam, waar baie wyfies nes gemaak het. Sodra die eiers wat gedurende die nag gelê is uit die nesse verwyder is, is die grond gehark, sodat nuwe nesse die volgende oggend maklik opgespoor kon word. Hoogstens 17 nesse is in een nag gelê. Dit is onbekend hoeveel wyfies daar in 2012 was toe die eiers gelê is, maar hulle het 207 nesse opgelewer met 8-77 eiers elk (gemiddeld 32, s 9.1), terwyl 166 nesse elk 1-47 broeilinge (gemiddeld 18.5, s 10.5) opgelewer het. Die oorsprong en verwantskap van die teeldiere is onbekend, behalwe dat die boer 10 mannetjies van 'n ander plaas ingebring het wat, so word aanvaar, onverwant is aan die diere wat reeds op die plaas was. Die verhoudig tussen die aantal mannetjies en wyfies was omtrent 1:10.

'n Vrugvliesmonster (VVM, meervoud VVMe) is van elke uitgebroeide eier in elk van 25 polistireen inkuberingskiste versamel. Elke kis het eiers van slegs een broeisel bevat en geen kis het eiers van dieselfde broeisel as ' $n$ ander bevat nie. Vir die meeste kiste waarvan die eiers gedurende die nag uitgebroei het is die monsters gedurende die volgende dag versamel. Vir die meeste kiste waar eiers gedurende die dag uitgebroei het is die monsters gedurende dieselfde dag versamel. Vir sommige kiste is die monsters 1-4 dae na uitbroeiing versamel.

Eiers is horisontaal gehou tydens inkubering en uitbroeiing. Die risiko het bestaan dat die vrugvlies in ' $n$ uitgebroeide eier met DNS van ander broeilinge gekontamineer kon word wanneer hulle oor die eier kruip. Terwyl die VVM versamel is, is die eier horisontaal gehou om die risiko te verminder dat vreemde materiaal deur sy oop pool ingaan. Die taai dopmembraan aan die binnekant van die dop skeur tydens uitbroeiing (Ferguson, 1982). Na uitbroeiing het die dopmembraan dikwels na 'n posisie teruggespring wat die gebreekte pool bedek en die risiko verminder het dat die eier se inhoud gekontamineer word. Indien die dopmembraan die gebreekte pool bedek het, is dit weggebuig of met'n skêr weggeknip om 'n opening te skep waardeur die VVM met 'n sitoborsel (Craig Brush, Cell Path Services, Johannesburg, Suid-Afrika) versamel is. Die sitoborsels was individueel verpak. Die nommers van die broeisel en die VVM is op die borsel se steel geskryf. Die borsel is lugdroog gemaak en in sy sakkie teruggeplaas.

Die nommers van die broeisel en die VVM is ook op die sakkie geskryf, waarna die sakkie vir omtrent 17 maande in 'n vrieskas teen $-18{ }^{\circ} \mathrm{C}$ geberg is voordat die DNS geëkstraheer is en die genotipe bepaal is. ' $n$ Groep van vier of vyf (in een geval ses) VVMe van elk van die 25 broede is gegenotipeer. (Voortaan word na daardie 4-6 VVMe wat gegenotipeerisofdaarnaaan'nbepaaldeprogrambewerking onderwerp is as ' $n$ groep verwys.)

\section{DNS ekstraksie}

Die borsel is in 'n Eppendorfbuis afgesny waarna $500 \mu \mathrm{L}$ lisebuffer van die "PrepFiler ${ }^{\mathrm{TM}}$ Automated Forensic DNA Extraction Kit" (ThermoFisher) bygevoeg is en die buis vir $60 \mathrm{~min}$ teen $70{ }^{\circ} \mathrm{C}$ (Vortemp 56, Labnet) geskud is. Dit is gevolg deur 'n geoutomeerde ekstraksieproses op 'n "Kinfisher 96 Magnetic Particle Processor" (ThermoFisher) volgens die Prepfiler ${ }^{\mathrm{TM}}$ V2 protokol (verskaf deur Applied Biosystems): DNS is vir 10 minute gebind en daarna 3 keer met $300 \mu \mathrm{L}$ Prepfiler ${ }^{\mathrm{TM}}$ wasoplossing gewas voordat dit vir 5 minute teen kamertemperatuur gedroog is en toe met $75 \mu \mathrm{L}$ uitwassingsbuffer uitgewas is.

\section{PKR en elektroforese}

Afgesien van die DNS ekstraksie uit die 110 VVMe is PKR en genotipering ook op 'n kontrolemonster gedoen. Die kontrolemonster was van 'n Nylkrokodil waarvan die DNS voorheen suksesvol vermenigvuldig het en waarvoor die genotipe bekend was.

Die PKR is op 'n "GeneAmp PCR System 9700 Thermal Cycler" (Life Technologies) gedoen, met 'n "KAPA2G Fast Multiplex PCR Kit" (Kapa Biosystems) en $4 \mu \mathrm{L}$ aanvangskodemengsel ("primer mix") in 'n $10 \mu \mathrm{L}$ reaksievolume.

Aanvangskodekonsentrasies was $0.1 \mathrm{nmol} / \mathrm{L}$ vir alle $\mathrm{KTH}$ merkers in mulitplekspaneel 1, $0.06 \mathrm{nmol} / \mathrm{L}$ vir $\mathrm{KTH}$ merker CpP4311 en $0.08 \mathrm{nmol} / \mathrm{L}$ vir al die ander $\mathrm{KTH}$ merkers in multiplekspaneel 2 (Tabel 1). Siklustoestande was 3 minute teen $95^{\circ} \mathrm{C}, 30$ siklusse van $95^{\circ} \mathrm{C}$ vir $15 \mathrm{~s}, 60^{\circ} \mathrm{C}$

TABEL 1: KTH (kort tandem herhaling) merkers is op grond van die kleurmerk en fragmentgrootte in twee multipleks PKR panele (1 en 2 ) saam vermenigvuldig.

\begin{tabular}{l|l|l|l|l|l|l}
\hline KTH ID & $\begin{array}{l}\text { Kleur } \\
\text { merk }\end{array}$ & $\begin{array}{l}\text { Multi- } \\
\text { pleks }\end{array}$ & $\begin{array}{l}\text { Minimum } \\
\text { alleel- } \\
\text { grootte }\end{array}$ & $\begin{array}{l}\text { Maksimum } \\
\text { alleel- } \\
\text { grootte }\end{array}$ & Voorwaartse aanvangskodevolgorde & Terugwaartse aanvangskodevolgorde \\
\hline CpDi06 & FAM & 1 & 236 & 274 & CAGTCGGGCGTCATCATGTTGGGCACTTTGAAC & GTTTAAGAAAAATGGTGGAAAAC \\
CpP801 & FAM & 1 & 159 & 195 & CAGTCGGGCGTCATCATTGGCATTAGATTGGTAGAC & GTTTCTATGCCAAAGCTACAAC \\
cpP4308 & FAM & 1 & 111 & 114 & CAGTCGGGCGTCATCACATATGTAAATTTGGAATGA & GTTTGATTGAGCCATCCTTAAC \\
CpDi28 & NED & 1 & 135 & 142 & CAGTCGGGCGTCATCACTATGCACTCCCTGATTTAAG & GTTTCCCACTCACGAATCTAAAG \\
CpDi21 & PET & 1 & 177 & 192 & CAGTCGGGCGTCATCAAAACAGTTGGCTCTGTG & GTTTATACTTCCTGTGGCATCAT \\
CpP309 & PET & 1 & 225 & 306 & GTTTAATACCTGGCATGTGTTCTTC & CAGTCGGGCGTCATCACATCAGGTTGGCATTTCA \\
CpP4006 & PET & 1 & 99 & 120 & CAGTCGGGCGTCATCAAGTGAGATTTGGGTATATTT & GTTTCATTTCCTTACCATGATAG \\
CpP4311 & NED & 2 & 211 & 241 & CAGTCGGGCGTCATCAGGCTGCTCTGTGTTTG & GTTTGGGTTTAGCATCATGT \\
CpDi42 & PET & 2 & 114 & 124 & GTTTTTCAGTTTATTTGCCAAAG & CAGTCGGGCGTCATCAGATTGGGGAGGGAAGT \\
CpP218 & PET & 2 & 164 & 187 & GTTTGGCATTTGAATTATTAACT & CAGTCGGGCGTCATCACTGGCAAATCACTTCTG \\
CpP314 & VIC & 2 & 260 & 279 & GTTTGAAATGCCACTAATACACACA & CAGTCGGGCGTCATCACCAATTCTTCAGGTCCTTAT \\
\hline
\end{tabular}


vir $30 \mathrm{~s}$ en $72{ }^{\circ} \mathrm{C}$ vir $30 \mathrm{~s}$, gevolg deur 'n verlengingstap teen $72{ }^{\circ} \mathrm{C}$ vir 10 minute. PKR produk $(0.5 \mu \mathrm{L})$ is met $10 \mu \mathrm{L}$ " $\mathrm{Hi}$ $\mathrm{Di}^{\mathrm{TM}}$ Formamide" (ThermoFisher) en $0.25 \mu \mathrm{L}$ "GeneScan ${ }^{\mathrm{TM}} 500$ LIZ $^{\mathrm{TM}}$ dye size standard" (ThermoFisher) gelaai en met 'n "3500xl Genetic Analyzer" (ThermoFisher) ontleed. Die data is met STRand sagteware (Universitit van Kalifornië - Davis) ontleed. Tabel 1 toon die besonderhede van die KTH merkers (mikrosatellietmerkers) en die multiplekspanele.

\section{Die gebruik van 'n doelgeskrewe program om 'n lokus se genotipes te beoordeel om broede met meer as een vaar te identifiseer}

Die enkellokus-minimum metode is die eenvoudigste om broede met meer as een vaar te identifiseer. Die aantal paternale allele by dié lokus met die meeste paternale allele in 'n broed word deur twee gedeel en opwaarts afgerond om die minimum aantal vaars in die broed te verkry (Jones, 2005). Ons het die genotipes by 'n lokus oor al die VVMe in 'n groep beoordeel om vas te stel of die groep minstens drie ouers het en, indien dit het, of die allele versoenbaar is met 'n gemeenskaplike ouer, wat ons aangeneem het dat dit die moeder is. 'n Program is in Python geskryf om die 4-6 (gemiddeld 4.26, s 0.56) VVMe in elke groep se genotipes by elk van 11 loki oor 'n totaal van 109 VVMe maklik te beoordeel. Bondigheidshalwe het ons die program $\mathrm{Al} 3 \mathrm{p} 1 \mathrm{c}$ genoem, wat staan vir "at least 3 parents with one in common". Al3p1c is, soos die enkellokus-minimum metode wat Jones (2005) beskryf het, ook 'n enkellokus metode. Die Pythonprogram verskyn in die bykomstige lêer "Crocodile_ Al3p1c.py". Alhoewel 110 VVMe gegenotipeer is, was een se genotipes by al 11 loki dieselfde as dié van 'n ander van dieselfde broed (sien Resultate). Hierdie VVM is van die ontleding met Al3p1c, sowel as met Gerud2.0 en Colony, soos hieronder beskryf, uitgesluit.

\section{Bepaling van die minimum aantal vaars in 'n broed met die gebruik van Gerud2.0}

Gerud2.0 neem veelvuldige loki in ag (Jones, 2005). Gerud2.0 stel eers alle moontlike multilokus maternale genotipes in 'n groep saam en daarna alle moontlike paternale genotipes, gebaseer op die maternale genotipes. Indien een multilokus paternale genotipe saam met 'n maternale genotipe al die genotipes in 'n groep verklaar, verklaar Gerud2.0 dat die groep net een vaar het of, indien twee multilokus paternale genotipes benodig word, dat die groep 'n minimum van twee vaars het, en so aan. Die minimum aantal vaars in elke groep VVMe is met Gerud2.0 bepaal. Gerud2.0 vereis dat die genotipe by alle loki wat gebruik word bekend is. In navolging van Bretman en Tregenza (2005) is al die VVMe in 'n groep wat 'n genotipe by elk van die drie mees inligtende loki (CpDi06, CpDi42 en CpP801) opgelewer het, gebruik om die minimum aantal vaars in die groep te bepaal.

\section{Die gebruik van Colony om die paternale geno- tipes af te lei en die aantal vaars in 'n groep te beraam}

Colony gebruik 'n berekeningsdoeltreffende waarskynlikheidsgebaseerde metode om sibskap en ouerskap tussen individue van hul multilokusgenotipe af te lei (Wang, 2004; Wang, 2012). Colony (Wang, 2004; Wang, 2012) kan by http://www.zsl.org/science/software / colony afgelaai word. Ons het die aantal vaars in 'n groep VVMe uit elk van 24 broede met Colony 2.0.6.5 beraam. Colony vereis dat DNS by minstens die helfte van die loki in elke individu moes vermenigvuldig (Colony se gebruikersgids). Minstens drie VVMe in 'n groep moet beoordeel word om vas te stel of die groep meer as een vaar mag hê. In 101 van die 110 VVMe het DNS in sewe of meer loki vermenigvuldig (in geen VVM het DNS in slegs ses loki vermenigvuldig nie). Die VVM wat identies aan 'n ander was en die enigste twee van groep 132 waar DNS by minstens sewe loki vermenigvuldig het is uitgesluit en die oorblywende 98 VVMe is gebruik. Hierdie 98 VVMe het bestaan uit 'n groep van 3-6 VVMe (gemiddeld 4.1, s 0.78) van elk van 24 broede. Ons het ses modelle gebruik waarin aangeneem is dat inteling nie plaasgevind het nie en dat die vaars en die moeders poligaam was. Die 24 maternale sibgroepe was by die modelle ingesluit. In die eerste model (model 1) het ons 'n genotiperingsfoutkoers van 0.1 en 'n alleeluitvalkoers van 0.1 aanvaar, met onbekende alleelfrekwensies (Sefc et al., 2008). Die uitkoms van hierdie model het 'n beraamde alleeluitvalkoers en genotiperingsfoutkoers vir elke lokus opgelewer wat ons in sommige van die daaropvolgende modelle gebruik het.

Ons het 'n stel van vier modelle (modelle 2-5) met onbekende alleelfrekwensies geloop. Elke model is drie keer geloop, elke keer met 'n ander saad vir die kansgetalskepper. In model 2 het ons die genotiperings- en die alleeluitvalkoerse vir elke lokus wat met model 1 beraam is gebruik. In model 3 het ons die genotiperings- en alleeluitvalkoerse vir elke lokus gelykgestel met die fraksie van die 98 genotipes wat homosigoties by die lokus was. (Hier het ons aangeneem dat oënskynlik homosigotiese genotipes een alleel gehad het wat nie vermenigvuldig het nie.) In model 4 het ons die genotiperings- en alleeluitvalkoers op elke lokus as nul gestel. (Alle oënskynlik homosigotiese genotipes is as werklik homosigoties beskou.) In model 5 is die alleeluitvalkoerse op nul gestel en die genotiperingsfoutkoerse op 'n baie lae vlak van 0.0001 vir elke lokus.

Tabel 3 van die resultate toon aan dat al ses modelle minder moeders beraam het as die 24 wat daar werklik was. Die aantal moeders wat deur die eerste en derde lopie van model 5 beraam is was die naaste aan die werklike aantal. Omdat die eerste lopie van model 5 een minder vaar beraam het as die derde lopie, is die eerste lopie aanvaar as dié een wat die waarskynlike aantal vaars per groep VVMe beraam het. 
Gebaseer op die eerste vyf modelle het ons 'n sesde model (model MinCol5) geloop. Model MinCol5 was dieselfde as model 5, behalwe dat die alleelfrekwensies gestel was volgens die Minimum Colony metode wat Sefc et al. (2008) en Sefc en Koblmüller (2009) beskryf het om die afgeleide aantal vaars te minimeer. Die frekwensie van elke alleel by elke lokus oor al 98 VVMe is op 0.0001 gestel, terwyl 'n niebestaande alleel by elke lokus gevoeg is waarvan die frekwensie só gestel is dat die som van die alleelfrekwensies by elke lokus een was.

Colony bring afwykings van Hardy-Weiberg ekwilibrium in berekening indien inteling as paringstelsel gekies word (Colony gebruikersgids). Ons het die effek van afwykings van Hardy-Weinberg ekwilibrium op die afleiding van vaderskap in berekening gebring deur 'n sewende model (model 5it) drie keer te loop. Model 5it het dieselfde ontledingsparameters as model 5 gebruik, behalwe dat inteling as paringstelsel gekies is. ' $n$ Gepaarde t-toets is gebruik om die gemiddelde aantal vaars per groep VVMe wat model 5it oor sy drie lopies afgelei het te vergelyk met die gemiddelde aantal wat oor model 5 se drie lopies afgelei is.

\section{Alleelfrekwensie-analise en uitsluitingswaar- skynlikheid}

Die moeders van die 24 broede en die 24 vaars wat in die eerste lopie van model 5 met Colony afgelei is, is as 'n lukraaksteekproef van die krokodilpopulasie in die teeldam beskou en ' $n$ alleelfrekwensie-analise is op hul afgeleide genotipes gedoen met Cervus 3.0.7 (Kalinowski et al., 2007). Waar die eerste lopie van model 5 afgelei het dat twee (dit was nooit meer as twee nie) groepe VVMe dieselfde moeder het, is die tweede groep aan 'n ander moeder toegeken met dieselfde genotipe as die eerste moeder. Hiervolgens het elke groep sy eie moeder, in ooreenstemming met die biologiese werklikheid. Die vaars wat Colony aan elk van die 24 groepe toegedeel het is so behou. Jamieson en Taylor (1997) het 'n vergelyking daargestel waarmee die alleelfrekwensies gebruik word om die waarskynlikheid te bereken waarmee 'n lukraak mannetjie, wat onverwant is aan die werklike vaar van 'n nakomeling, as vaar uitgesluit word indien slegs die nakomeling se genotipe bekend is. Voortaan verwys ons hierna as die uitsluitingswaarskynlikheid of UW. Cervus gebruik Jamieson en Taylor se vergelyking en rapporteer die NEP-1P as die waarskynlikheid dat 'n lukraakgekose mannetjie wat onverwant is aan die vaar nié as vaar uitgesluit word nie indien slegs die nakomeling se genotipe bekend is. (NE-1P staan vir "non-exclusion probability for one parent" en ons verwys hierna as NUW-1O, wat staan vir die nie-uitsluitingswaarskynlikheid van een ouer.) Ons het vergelyking (6) in Wang (2007) gebruik om WUn te bereken, waar WUn die waarskynlikheid is dat 'n lukraakgekose mannetjie wat onverwant is aan 'n groep se vaar, as vaar uitgesluit word vir groepe van van een tot vyf volsibbe. In WUn is $n$ die aantal volsibbe in die groep waarvoor die genotipe bekend is.

\section{Resultate \\ Die gereeldheid waarmee vermenigvuldiging misluk het}

Die bykomstige lêer genaamd "Crocodile_genotypes.csv" toon die genotipes by alle loki van die 110 VVMe.

Die kontrolemonster het ' $n$ volledige genotipe by elke lokus opgelewer, wat aandui dat die PKR, elektroforese en genotipering na verwagting presteer het. DNS het in 91 (7.5\%) van die 1210 moontlike genotipes nie vermenigvuldig nie. Vermenigvuldiging het by alle loki misluk in twee VVMe, by 9-10 loki in drie, by 7-8 loki in drie, by ses loki in een, by vier loki in een, by 2-3 loki in twee en by een lokus in drie van die VVMe. In die oorblywende 95 (86.4\%) van die VVMe het vermenigvuldiging by alle loki plaasgevind.

Sodra 'n broeiling uitgebroei het kon dit oor ander uitgebroeide eiers kruip en moontlik die DNS van hul vrugvliese kontamineer. Sulke kontaminering mag daartoe lei dat 'n VVM meer as twee allele by 'n lokus oplewer. Die broede waaruit die 25 groepe VVMe versamel is het uit sewe tot 39 (gemiddeld 23) broeilinge bestaan. Tóg het geen VVM meer as twee allele by 'n lokus getoon nie, wat aandui dat geen VVM se DNS met dié van 'n ander individu gekontamineer is nie.

Davis et al. (2001) het slegs vyf polimorfiese mikrosatellietloki gebruik en Amerikaanse alligatorbroeilinge uit dieselfde broed gevind met dieselfde multilokusgenotipe. In die huidige studie was VVM 21 en VVM 23 van broed 098 se genotipes dieselfde op alle loki.

Groepe VVMe met meer as een vaar wat met die doelgeskrewe program Al3p1c uitgeken is Al3p1c het aangedui dat omtrent die helfte van die 25 VVM-groepe meer as een vaar het. Slegs twee van die 11 loki (CpP309 and $\mathrm{CpP} 4006$ ) het geen aanduiding gegee dat enige groep meer as een vaar het nie. Die nege loki waar die VVMe van minstens een groep drie of meer allele getoon het verskyn in Tabel 2. Indien oënskynlik homosigotiese loki werklik homosigoties was en skaars allele nie die gevolg van foute nie, het 13 van die 25 VVM-groepe elk minstens een lokus (1-5, gemiddeld $2.0, \mathrm{~s} 1.2)$ wat op minstens twee vaars dui (Tabel 2). Hieruit volg dat Al3p1c minstens 38 volsibgroepe geïdentifiseer het.

Alleelwegval en vals skaars allele mag die fraksie van VVM-groepe waarvoor afgelei word dat hulle meer as een vaarhet, verhoog. Selfs indien alle oënskynlik homosigotiese loki die gevolg van alleelwegval en alle skaars allele die gevolg van foute was, het 11 van die 25 VVM-groepe elk minstens een (gemiddeld 1.33, s 0.65) lokus wat aandui dat die broed minstens twee vaars het. 


\section{Die minimum aantal vaars in 'n broed soos bepaal met Gerud2.0}

Aanvanklik het Gerud2.0 aangedui dat 13 VVM-groepe een vaar het en 11 minstens twee. Onder die 13 groepe met een vaar was VVM-groep 079 waarvoor $\mathrm{Al} 3 \mathrm{p} 1 \mathrm{c}$ aangedui het dat dit minstens twee vaars het (Tabel 2). Afgesien van groep 079 was die ander 12 VVM-groepe met een vaar volgens Gerud2.0 dieselfde as dié wat volgens Al3p1c net een vaar het. Al3p1c het by loki CpP218 en CpP4308 aangedui dat groep 079 minstens drie paternale allele het (Tabel 2). Indien hierdie loki by die ontleding van groep 079 met Gerud2.0 ingesluit is, het Gerud2.0 ook aangedui dat broed 079 minstens twee vaars het.

Afgesien van VVM-groep 132 wat nie met Gerud2.0 ontleed is nie, omdat dit slegs twee VVMe gehad het wat genotipes by al drie die loki wat met Gerud2.0 ontleed is, het Gerud2.0 vir dieselfde 12 VVM-groepe as Al3p1c (Tabel 2) aangedui dat hulle minstens twee vaars het. Uiteindelik het Gerud2.0 dus aangedui dat 12 VVM-groepe een vaar het en 12 minstens twee. Gerud2.0 het aangedui dat die 24 VVMgroepe wat daarmee ontleed is minstens 36 volsibgroepe bevat het.

\section{Oorsig van die resultate wat met die oor- spronklike ses modelle van Colony behaal is}

Met modelle 1-5 en model MinCol5, wat almal gebaseer was op paring sonder inteling, het Colony afgelei dat daar beduidend minder moeders was as die 24 wat daar werklik was (Tabel 3). Colony het nooit enige van die 24 werklike maternale sibgroepe verdeel en die gedeeltes van 'n sibgroep aan verskillende moeders toegewys nie, maar dit het twee of meer hele maternale sibgroepe gekombineer en aan dieselfde afgeleide moeder toegewys. Die onderskatting van die aantal moeders was veral erg met model 1 en model MinCol5. Die aantal moeders wat met die drie lopies van model 5 afgelei is was die naaste aan die werklike aantal van 24 (Tabel 3). Al ses modelle sonder inteling het afgelei dat minstens 17 van die 24 VVM-groepe meer as een vaar gehad het (Tabel 3).

Die resultate wat met model 5it behaal is in vergelyking met dié van model 5 demonstreer die effek wat inteling en afwyking van Hardy-Weinberg ekwilibrium op die afleiding van vaderskap het. As gemiddeld oor drie lopies is met model 5 it afgelei dat die 24 VVM-groepe 27.3 vaars gehad het en met model 5 was dit 25.3. Met model 5 it is 'n gemiddeld van 2.60 (s 1.04, $\mathrm{n}=24$ ) vaars per VVM-groep oor drie lopies afgelei, wat waarskynlik nie verskil het van die 2.65 (s 1.06, n = 24) wat oor die drie lopies met model 5 afgelei is nie $(\mathrm{P}=0.1)$. Colony het met model 5it 'n soortgelyke aantal moeders, volsibgroepe en VVM-groepe met meer as een vaar afgelei as met model 5 (Tabel 3). Behalwe vir die resultate in Tabel 3, verwys alle verdere resultate na dié wat met die eerste lopie van model 5 behaal is.

\section{Resultate met die eerste lopie van model 5}

\section{Alleelfrekwensie-analise en uitsluitingswaarskynlikheid}

Behalwe vir een alleel op lokus CpDi21, het die genotipes van die 48 ouers wat met die eerste lopie van model 5 afgelei is, al die allele wat in die 110 gegenotipeerde VVMe gevind is getoon. Die resultaat van die frekwensie-analise van die allele in die 48 afgeleide ouers verskyn in Tabel 4 . Drie tot 20 (gemiddeld 6.8, s 4.75) allele is per lokus gevind. Die gemiddelde waargenome- en verwagte heterosigositeit was 0.54 en 0.64 . Die waargenome heterosigositeit was laer as die verwagte in al die loki behalwe een. Dit is onwaarskynlik dat die genotipes by vier loki in HardyWeinberg ekwilibrium was $(P<0.05)$. Die gekombineerde uitsluitingswaarskynlikheid oor al 11 loki vir'n volsibgroep wat uit een individu bestaan, was 0.963295 en vir subgroepe wat uit meer as een individu bestaan het was dit bokant 0.990 (Tabel 4). Die gemiddelde uitsluitingswaarskynlikheid oor al 65 afgeleide volsibgroepe, geweeg volgens die grootte van elke volsibgroep was 0.972421 .

TABEL 2: Loki waar die Al3p1c-program aangedui het dat 25 groepe van 4-6 vrugvliesmonsters (totaal 109) van elk van 25 Nylkrokodilbroede (Crocodylus niloticus) minstens drie paternale allele gehad het, wat aandui dat die broed minstens twee vaars het

\begin{tabular}{|c|c|c|c|c|c|c|c|c|c|c|}
\hline \multirow[b]{2}{*}{ Broednommer } & \multirow[b]{2}{*}{ VVM (n) } & \multicolumn{9}{|c|}{ Loki } \\
\hline & & CpDi06 & CpDi21 & CpDi28 & CpDi42 & CpP218 & CpP314 & CpP4308 & CpP4311 & CpP801 \\
\hline 053 & $4^{\mathrm{a}}$ & $3^{b}$ & & & & & & & & \\
\hline 061 & 5 & & & & 4 & 3 & & & 3 & \\
\hline 079 & 4 & & & & & 3 & & 3 & & \\
\hline 084 & 4 & 3 & & & 4 & & & & & \\
\hline 094 & 3 & & & 3 & 3 & & & & & 3 \\
\hline 097 & 6 & & & & & & & & & 3 \\
\hline 126 & 4 & 3 & & & & 3 & 3 & 3 & & 4 \\
\hline 127 & 4 & & & & 4 & & & & & 4 \\
\hline 128 & 5 & 3 & & & & & & & & \\
\hline 132 & 4 & & & & & & & & & 3 \\
\hline 138 & 4 & 4 & & & & & & & & \\
\hline 146 & 4 & 3 & & & & & & & & \\
\hline 149 & 5 & 4 & 3 & & 4 & & & & & \\
\hline
\end{tabular}

${ }^{a}$ Die syfers in hierdie kolom toon die aantal uitgebroeide eiers waarvan 'n vrugvliesmonster (VVM) gegenotipeer is. ${ }^{b}$ Syfers onder en regs van hierdie een toon die aantal paternale allele in die VVMe van die broed wat gegenotipeer is. 


\section{Broede met meer as een afgeleide vaar onder die gegenotipeerde VVMe}

Poliandrie was algemeen. Slegs vyf van die 24 VVM-groepe het een vaar, terwyl twee derdes van die groepe drie of meer het (Figuur 1a). VVM-groepe het gemiddeld 2.71 (s 1.08) vaars. Vyf van die 19 VVM-groepe het eweveel vaars as VVMe wat met Colony ontleed is, wat daarop dui dat meer vaars geïdentifiseer sou word indien meer VVMe tot daardie groepe gevoeg sou word. Die poliandrie het gelei tot 'n groot aantal klein volsibgroepe (gemiddeld 1.51 volsibbe per groep, s $0.99, \mathrm{n}=65)$. Vyf en veertig $(69 \%)$ van die volsibgroepe het uit een nakomeling bestaan (Figuur $1 b)$.
Poliginie was ook algemeen. Negentien van die 24 vaars het nageslag in meer as een VVM-groep met ' $n$ derde van die vaars wat nageslag in 4-5 VVM-groepe het (Figuur 1c). Vaars het nageslag in gemiddeld 2.71 (s 1.23) VVM-groepe.

Die vrugbaarheid van vaars het gevarieer (Figuur 1d). Vaars het elk 1-9 nakomelinge verwek met ' $n$ gemiddeld van 4.08 (s $2.50, \mathrm{n}=24$ vaars). Sewe van die 24 vaars ( $29 \%)$ het elk 6-9 nakomelinge verwek, wat $52 \%$ van al die nakomelinge beslaan.

TABEL 3: Die aantal vaars en moeders wat Colony afgelei het in 98 vrugvliesmonsters (VVMe) wat bestaan het uit 'n groep van 3-6 VVMe uit elk van 24 Nylkrokodil (Crocodylus niloticus) broede

\begin{tabular}{|c|c|c|c|c|c|}
\hline Model & Lopie & Aantal vaars & Groepe VVMe met meer as een vaar & Aantal moeders & Aantal volsibgroepe \\
\hline Model 1 & 1 & 19 & 20 & 14 & 59 \\
\hline Model 2 & 1 & 23 & 21 & 18 & 60 \\
\hline Model 2 & 2 & 23 & 18 & 17 & 57 \\
\hline Model 2 & 3 & 23 & 20 & 17 & 63 \\
\hline Model 3 & 1 & 27 & 19 & 16 & 57 \\
\hline Model 3 & 2 & 22 & 18 & 15 & 51 \\
\hline Model 3 & 3 & 26 & 18 & 16 & 56 \\
\hline Model 4 & 1 & 24 & 19 & 17 & 62 \\
\hline Model 4 & 2 & 25 & 19 & 17 & 60 \\
\hline Model 4 & 3 & 23 & 21 & 18 & 61 \\
\hline Model 5 & 1 & 24 & 19 & 20 & 65 \\
\hline Model 5 & 2 & 27 & 18 & 19 & 62 \\
\hline Model 5 & 3 & 25 & 20 & 20 & 62 \\
\hline MinCol5 & 1 & 20 & 17 & 14 & 56 \\
\hline MinCol5 & 2 & 20 & 18 & 15 & 58 \\
\hline MinCol5 & 3 & 19 & 18 & 15 & 57 \\
\hline Model 5it & 1 & 27 & 20 & 20 & 62 \\
\hline Model 5it & 2 & 30 & 21 & 20 & 62 \\
\hline Model 5it & 3 & 25 & 18 & 19 & 60 \\
\hline
\end{tabular}

TABEL 4: Opsomming van die alleelfrekwensie-analise op elke lokus in die 48 afgeleide ouers van groepe van 3-6 nakomelinge (vrugvliesmonsters) uit 24 broede uit die enigste teeldam op 'n kommersiële Nylkrokodil (Crocodylus niloticus) plaas

\begin{tabular}{l|c|c|c|c|c|c|c|c|c|c}
\hline Lokus & $\mathbf{K}^{\mathbf{a}}$ & Hw $^{\mathbf{b}}$ & Hv $^{\mathbf{c}}$ & HWE $^{\mathbf{d}}$ & Fnul $^{\mathbf{e}}$ & VSG1 $^{\mathbf{f}}$ & VSG2 $^{\mathbf{g}}$ & VSG3 $^{\mathbf{h}}$ & VSG4 $^{\mathbf{i}}$ & VSG5 $^{\mathbf{j}}$ \\
\hline CpDi06 & 20 & 0.708 & 0.796 & 0.4004 & 0.0582 & 0.453661 & 0.559054 & 0.634461 & 0.678396 & 0.702336 \\
CpDi21 & 5 & 0.417 & 0.468 & 0.9321 & 0.0391 & 0.109199 & 0.15306 & 0.184045 & 0.203755 & 0.216128 \\
CpDi28 & 6 & 0.688 & 0.634 & 0.2275 & -0.0671 & 0.218805 & 0.297909 & 0.354885 & 0.389832 & 0.410497 \\
CpDi42 & 10 & 0.583 & 0.816 & 0.001 & 0.1545 & 0.453054 & 0.573843 & 0.655514 & 0.702736 & 0.728744 \\
CpP218 & 5 & 0.396 & 0.524 & 0.006 & 0.1557 & 0.146453 & 0.200184 & 0.24249 & 0.268944 & 0.284576 \\
CpP309 & 4 & 0.417 & 0.58 & 0.0330 & 0.1617 & 0.166903 & 0.235184 & 0.279449 & 0.306904 & 0.324057 \\
CpP314 & 6 & 0.604 & 0.663 & 0.0141 & 0.0659 & 0.2486 & 0.335032 & 0.39792 & 0.436164 & 0.458399 \\
CpP4006 & 3 & 0.354 & 0.504 & 0.0866 & 0.1707 & 0.124242 & 0.174878 & 0.209234 & 0.231016 & 0.244815 \\
CpP4308 & 5 & 0.563 & 0.659 & 0.4894 & 0.0753 & 0.251728 & 0.337022 & 0.400856 & 0.439602 & 0.461831 \\
CpP4311 & 4 & 0.604 & 0.628 & 0.9007 & 0.0141 & 0.212153 & 0.290153 & 0.34668 & 0.381446 & 0.402046 \\
CpP801 & 7 & 0.583 & 0.757 & 0.1035 & 0.1310 & 0.36012 & 0.47095 & 0.549214 & 0.595477 & 0.621455 \\
Alle loki saam & & & & & & 0.963295 & 0.990663 & 0.996961 & 0.998569 & 0.999101 \\
\hline
\end{tabular}

${ }^{a}$ Aantal allele wat op elke lokus gevind is. ${ }^{b}$ Waargenome heterosigositeit. ${ }^{c}$ Verwagte heterosigositeit. ${ }^{d}$ Die waarskynlikheid (sonder Bonferroni korreksie) dat so groot of 'n groter afwyking tussen die waargenome frekwensies van genotipes en dié wat onder Hardy-Weinberg ekwilibrium te wagte is toevallig sou voorkom. ${ }^{\mathrm{e}}$ Die geskatte frekwensie van nulallele. ${ }^{f-j}$ Die waarskynlikheid dat ' $n$ lukraak-gekose mannetjie in die populasie, wat onverwant is aan die werklike vaar van ' $n$ volsibgroep, as vaar uitgesluit sal word indien een $\left({ }^{f}\right)$, twee $\left({ }^{g}\right)$, drie $\left({ }^{h}\right)$, vier $\left({ }^{(}\right)$of vyf $\left({ }^{j}\right)$ lede van 'n volsibgroep gegenotipeer is. 


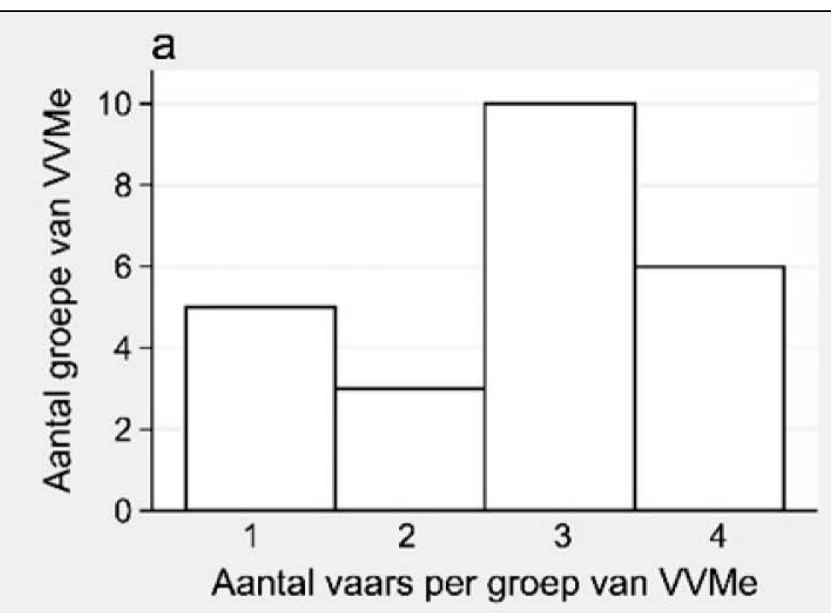

C

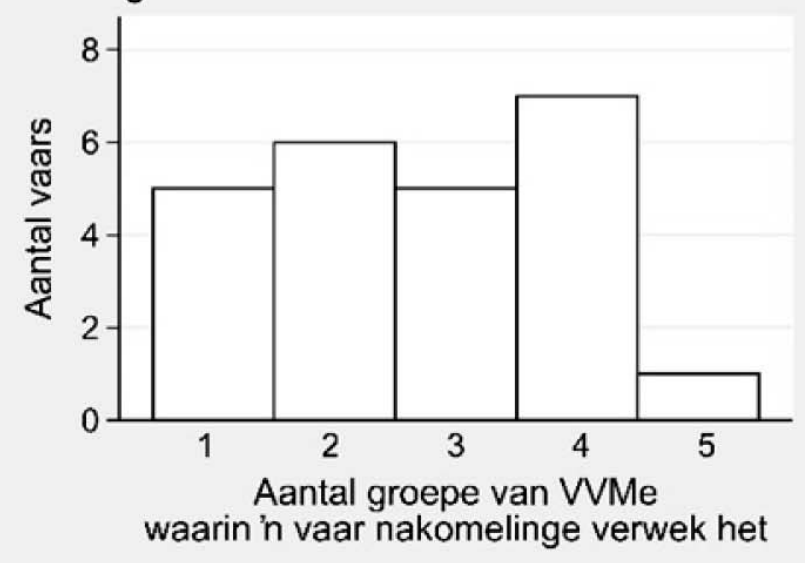

b

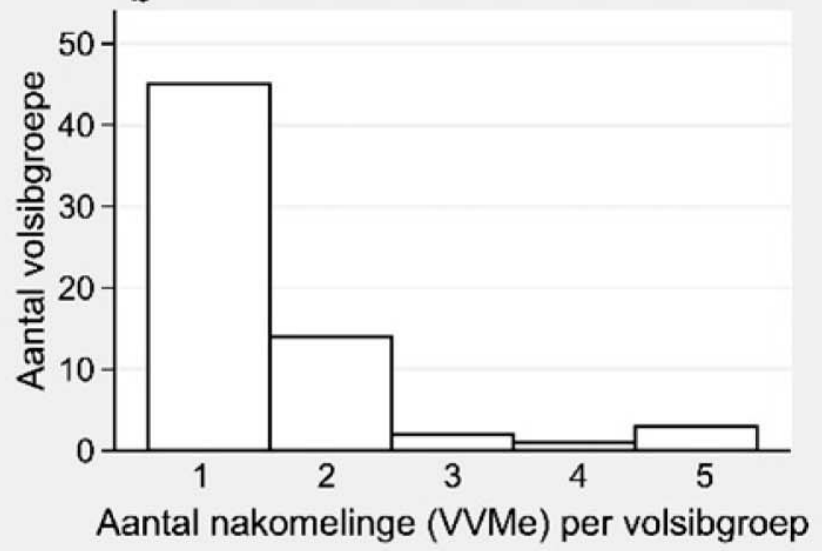

d

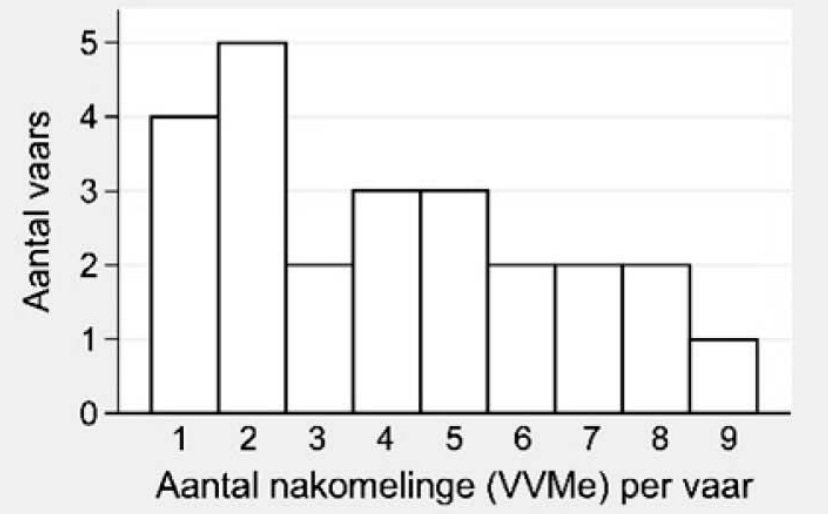

FIGUUR 1: Die omvang van poliandrie (a), frekwensie van volsibgroepe van verskillende groottes (b), omvang van poliginie (c) en vrugbaarheid van vaars (d), waar vaars en volsibgroepe afgelei is van groepe van 3-6 vrugvliesmonsters (VVMe) van elk van 24 Nylkrokodil (Crocodylus niloticus) broede

\section{Bespreking}

Die eerste doel van hierdie studie was om vas te stel of vrugvliese in Nylkrokodil (Crocodylus niloticus) eiers kort na uitbroeiing DNS kan verskaf wat suksesvol vermenigvuldig. Oor die 110 VVMe kon $7.5 \%$ van die 1210 genotipes nie bepaal word nie, omdat die DNS nie vermenigvuldig het nie. Vermenigvuldiging het in minstens een lokus in 15 VVMe gefaal, met faling in van die helfte tot al 11 loki in nege van die 15, wat daarop dui dat die DNSpatroon ("template") hier van onvoldoende hoeveelheid of -gehalte was om te vermenigvuldig (Gagneaux et al., 1997). Vermenigvuldiging het egter by alle loki van 95 (86.4\%) van VVMe plaasgevind, en VVMe is dus 'n goeie bron van DNS in die Nylkrokodil. Dit is onwaarskynlik dat vrugvliese van een eier met DNS van ' $n$ broeiling uit ' $n$ ander eier in dieselfde kis gekontamineer is, omdat geen lokus in enige individu meer as twee allele getoon het nie.

Die tweede doel van hierdie studie was om vas te stel of 'n Nylkrokodilbroed uit 'n kommunale teeldam op 'n kommersiële plaas meer as een vaar kan hê. Colony het afgelei dat 19 VVM-groepe meer as een vaar het, wat beduidend meer is as die 12 wat met Al3p1c en Gerud2.0 in dieselfde 24 VVM-groepe geïdentifiseer is. Ons bevindings stem ooreen met dié van Sefc et al. (2008) dat Colony 'n groter fraksie van broede met veelvuldige vaars aandui as die enkellokus-minimum metode en Gerud2.0. Nietemin het selfs Al3p1c, wat die mees konserwatiewe metode in hierdie studie was om poliandrie mee te identifiseer, getoon dat sommige Nylkrokodilbroede meer as een vaar het.

Colony het nie slegs afgelei watter VVM-groepe meer as een vaar het nie, maar ook die waarskynlikste volsibstruktuur en die waarskynlikste aantal vaars in elke VVM-groep. Die akkuraatheid van hierdie afleidings hang af van die waarskynlikheid dat Colony enige mannetjie in die populasie wat onverwant is aan die werklike vaar as vaar sal uitsluit. Met in agneming van al die nakomelinge in elk van die 65 afgeleide volsibgroepe (Wang, 2007) is die uitsluitingswaarskynlikheid 0.9724. Die waarskynlikheid dat Colony verkeerdelik ' $n$ vaar aan ' $n$ VVM toewys is dus $2.8 \%$. Die toewysing van vaars behoort daarom vir die oorgrote meerderheid VVMe korrek te wees.

Alhoewel die hoë uitsluitingswaarskynlikheid aandui dat Colony vaars meesal korrek aan die 3-6 VVMe in die 24 VVM-groepe toegewys het, was die broede waaruit die VVMe bekom is oor die algemeen groot, met gemiddeld 23 
broeilinge. Nadat hulle gemiddeld 29.2, 19.6 en 18.8 broeilinge per broed van die Amerikaanse alligator (Davis et al., 2001; Lance et al., 2009) en Morelet se krokodil (McVay et al., 2008) gegenotipeer het, het die outeurs getoon dat, in broede met meer as een vaar, die fraksies van broeilinge wat deur die primêre vaar verwek is in verhouding tot dié wat deur die ander vaars verwek is baie skeef is. In die lig hiervan is die aantal vaars per broed in die huidige studie waarskynlik hoër as die aantal wat per VVM-groep van 4.1 (gemiddeld) VVMe afgelei is. Die lae aantal VVMe per broed wat gegenotipeer is laat ons nie toe om enige afleiding te maak oor die aantal vaars in die hele broed nie.

Sefc et al. (2008) het bevind dat MinCol (minimum Colony soos hulle daarna verwys) die aantal vaars per broed korrek afgelei het indien daar twee of vier vaars per broed was en die aantal met een onderskat het in $35 \%$ van broede met vyf vaars, terwyl Colony die ware aantal vaars per broed dikwels oorskat het. Deur broede van 25 wat bestaan uit vier klein subgroepe van drie en een van 13 te gebruik het Sefc en Koblmüller (2009) bevind dat MinCol (MIN soos hulle daarna verwys) die aantal vaars per broed onderskat het terwyl Colony die aantal vaars oor die gemiddeld binne een van die werklike aantal geskat het. Die bevindings van die huidige studie dat die MinCol model 56-58 volsibgroepe oor al 24 VVM-groepe afgelei het en Colony (eerste lopie van model 5) ietwat meer teen 65 , stem ooreen met die neigings wat Sefc et al. (2008) en Sefc en Koblmüller (2009) gevind het. Die 38 volsibgroepe wat Al3p1c oor al 25 VVMgroepe bevind het is beduidend minder as die aantal wat met MinCol en Colony afgelei is. Net so het Sefc et al. (2008) bevind dat die enkellokus-minimum metode minder vaars per broed afgelei het as die MinCol metode, wat weer minder vaars per broed afgelei het as Colony.

Davis et al. (2001) het bevind dat Amerikaanse alligatormannetjies nageslag in meer as een broed per seisoen kan verwek. Net so het die huidige studie ook getoon dat Nylkrokodilmannetjies op 'n kommersiële plaas ook nageslag in meer as een broed kan hê, met een derde van die 24 afgeleide vaars wat nageslag in minstens drie broede gehad het.

Dit is onwaarskynlik $(\mathrm{P}<0.05)$ dat die allele van die ouers wat met model 5 afgelei is by vier van die 11 loki in HardyWeinberg ekwilibrium was. Vaderskap soos afgelei met model 5it, wat inteling en afwyking van Hardy-Weinberg ekwilibrium in ag geneem het, het nie beduidend van dié wat met model 5 afgelei is verskil nie.

Verdere navorsing is nodig waarin meer nakomelinge per broeisel gegenotipeer word om die omvang van poliandrie en poliginie in teeldamme op kommersiële plase meer presies te bepaal. Hierdie studie dui op 'n nut vir verdere navorsing om vas te stel of fenotipiese eienskappe wat vir kommersiële boere belangrik is, soos groei, verpotting en mortaliteit van broeilinge (Brien et al., 2014) verband hou met verskille in vaderskap.
Populasiedigtheid, migrasie en territoriale gedrag van Nylkrokodille in die natuur mag verskil van dié op kommersiële plase. Die omvang van poliandrie, poliginie, die grootte van volsibgroepe en vrugbaarheid van mannetjies in die natuur mag dus ook verskil van dié wat ons op 'n kommersiële plaas gevind het. Hierdie verskynsels behoort ook in Nylkrokodilpopulasies in die natuur bestudeer te word.

In die natuur maak 'n Nylkrokodilwyfie die nes oop sodra die eiers uitbroei, dan versamel sy die broeilinge in haar bek en dra hulle water toe (Combrink et al., 2016). Moderne tegnologie behoort dit moontlik te maak om nesse in die natuur te moniteer en vas te stel wanneer die moeder die broeilinge uit die nes haal. Dit behoort mens toe te laat om spoedig die vrugvliese van die eieroorblyfsels te bekom om vas te stel of hulle ongekontamineerde genotipes van die broeilinge oplewer. Indien suksesvol, sou dit 'n nieingrypende model daarstel om paringspatrone van Nylkrokodille in die natuur te bestudeer.

\section{Gevolgtrekking}

Vrugvliese in uitgebroeide Nylkrokodileiers is 'n geskikte bron van DNS om die genetiese profiele van broeilinge te bepaal. Genotipering van 4-5 nakomelinge per broeisel (ses in een broeisel) het getoon dat minstens die helfte en waarskynlik minstens 19 van 24 Nylkrokodilbroede van 'n kommunale teeldam op 'n kommersiële plaas meer as een vaar het en dat vaars dikwels nageslag in meer as een broed het.

\section{Outeursbydraes}

$\mathrm{CH}$ het die paneel van $\mathrm{KTH}$ merkers gekies, toesig gehou oor die prosedures in die Veterinêre Genetika Laboratorium en die identiteit van die allele bevestig. JGM en JON het die vrugvliesmonsters versamel. JAN het die rekenaaralgoritmes vir Al3p1c geskryf. JON het die idee vir die studie verskaf en die data-analise gedoen, die manuskrip geskryf en in Afrikaans vertaal.

\section{Erkennings}

Die outeurs bedank die personeel van Le Croc Estate vir die geleentheid om materiaal te versamel. Ons bedank ook die Nasionale Navorsingstigting, omdat die aansporingsfonds vir goedgekeurde navorsers (fonds 85836) wat aan JON toegeken is die studie gedeeltelik befonds het. Ons bedank die twee beoordelaars wie se kritiek, kommentaar en aanbevelings tot 'n baie beter artikel gelei het en M.M. Nöthling (JON se eggenote) vir die verbetering van die Afrikaanse vertaling.

\section{Verwysings}

Amavet P, Rosso E, Markariani R, Piña Cl. 2008. Microsatellite DNA markers applied to detection of multiple paternity in Caiman latirostris in Santa Fe, Argentina. Journal of Experimental Zoology 309A:637-642. DOI 10.1002/jez.496.

Bretman A, Tregenza T. 2005. Measuring polyandry in wild populations: a case study using promiscuous crickets, Molecular Ecology 14, 2169-2179. doi: 10.1111/j.1365-294X.2005.02556.x. 
Brien ML, Webb GJ, McGuinness K, Christian KA. 2014. The relationship between early growth and survival of hatchling saltwater crocodiles (Crocodylus porosus) in captivity. Plos One 9 (6):e100276.

Combrink X, Warner JK, Colleen T, Downs CT. 2016. Nest predation and maternal care in the Nile crocodile (Crocodylus niloticus) at Lake St Lucia, South Africa. Behavioural Processes 133, 31-36. http://dx.doi.org/10.1016/j. beproc.2016.10.014.

Davis LM, Glenn TC, Elsey RM, Dessauer HC, Sawyer RH. 2001. Multiple paternity and mating patterns in the American alligator, Alligator mississippiensis. Molecular Ecology 10, 1011-1024.

Ferguson MWJ. 1982. The structure and composition of the eggshell and embryonic membranes of Alligator mississippiensis. Transactions of the Zoological Society of London 36, 99-152.

Fitzsimmons NN, Tanksley S, Forstner MRJ, Louis EE, et al. 2000. Microsatellite markers for Crocodylus: new genetic tools for population genetics, matin system studies and forensics, in: Grigg, G.C., Seebacher, F., Franklin, C.E. (Eds.) Crocodilian biology and evolution. Surrey Beatty \& Sons, Chipping Norton, pp. $51-57$.

Gagneux P, Boesch C, Woodruff DS. 1997. Microsatellite scoring errors associated with noninvasive genotyping based on nuclear DNA amplified from shed hair. Molecular Ecology 6, 861-868.

Hartl DL, 2000. A primer of population genetics. Third edition. Sinauer Associates, Inc. Publishers, Sunderland, Massachusetts, USA.

Huchzermeyer FW. 2003. Crocodiles: Biology, husbandry and diseases. CAB Publishing, Cambridge, MA, USA.

Hutton JM. 1987. Incubation temperatures, sex ratios and sex determination in population of Nile crocodiles (Crocodylus niloticus). Journal of Zoology 211 143-155.

Jamieson A, Taylor SCS. 1997. Comparisons of three probability equations for parentage exclusion, Animal Genetics 28, 397-400.

Jones AG. 2005. GERUD2.0: A computer program for the reconstruction of parental genotypes from half-sib progeny arrays with known or unknown parents, Molecular Ecology Notes 5, 708-711 doi: 10.1111/j.1471-8286.2005.01029.x.

Kalinowski ST, Taper ML, Marshall TC. 2007. Revising how the computer program CERVUS accommodates genotyping error increases success in paternity assignment Molecular Ecology 16, 1099-1106. DOI 10.1111/j.1365294X.2007.03089.x

Khosa P, Imbayarwo-Chikosi VE, Hamandishe V. 2012. Comparative analysis of hatching rates and clutch sizes of Nile crocodile (Crocodylus niloticus) eggs collected on- and off-farm in Zimbabwe. Tropical Animal Health and Production 44, 905-909. DOI 10.1007/s11250-011-9985-z.

Kofron CP. 1989. Nesting ecology of the Nile crocodile (Crocodylus niloticus). African Journal of Ecology 27, 335-341.

Kofron CP. 1990. The reproductive cycle of the Nile crocodile (Crocodylus niloticus). Journal of Zoology 221, 477-488.

Lafferriere NAR, Antelo R, Alda F, Mårtensson D, et al. 2016. Multiple paternity in a reintroduced population of the Orinoco crocodile (Crocodylus intermedius) at the El Frío Biological Station, Venezuela. PLoS ONE 11(3): e0150245. DO 10.1371 / journal.pone.0150245.

Lance SL, Tuberville TD, Dueck L, Holz-Schietinger C, et al. 2009. Multiyear multiple paternity and mate fidelity in the American alligator, Alligator mississippiensis. Molecular Ecology 18, 4508-4520. DOI 10.1111/j.1365-294X.2009.04373.x.
Litt M, Luty JA. 1989. A hypervariable microsatellite revealed by in vitro amplification of a dinucleotide repeat within the cardiac muscle actin gene. Am. J. Hum. Genet. 44, 397-401.

McGeady TA, Quinn PJ, Fitzpatrick ES, Ryan MT, et al. 2017. Veterinary Embryology, second edition. John Wiley and Sons, Chichester, West Sussex, UK.

McVay JD, Rodriguez D, Rainwater TR, Dever JA, et al. 2008. Evidence of multiple paternity in Morelet's Crocodile (Crocody/us moreletii) in Belize, CA, inferred from microsatellite markers. Journal of Experimental Zoology 309A, 643-648. DOI 10.1002/jez.500.

Miesfeld R, Krystal M, Arnheim N. 1981. A member of a new repeated sequence family which is conserved throughout eucaryotic evolution is found between the human $\delta$ and $\beta$ globin genes. Nucleic Acids Research 9 (22), 5931-5947.

Miles LG, Lance SL, Isberg SR, Moran C, Glenn TC. 2009. Cross-species amplification of microsatellites in crocodilians: assessment and applications for the future. Conservation Genetics 10, 935-954. DOI 10.1007/s10592-008-9601-6.

Muniz FL, Da Silveira R, Campos Z, Magnusson WE, et al. 2011. Multiple paternity in the Black Caiman (Melanosuchus niger) population in the Anavilhanas National Park, Brazilian Amazonia. Amphibia-Reptilia 32, 428-434. DO 10.1163/017353711X587741.

Nöthling JO, Nöthling JA, Myburgh JG. 2019a. 'n Model om Nylkrokodileiers se volumes mee te skat nadat hulle uitgebroei het, Suid-Afrikaanse Tydskrif vir Natuurwetenskap en Tegnologie 38(1). Afrikaanse manuskrip besikbaar by satnt.co.za/index.php/satnt/article/view/680. English manuscript available at satnt.co.za/index.php/satnt/article/view/680. English
satnt.co.za/index.php/satnt/article/view/680/1533.

Nöthling JO, Nöthling JA, Myburgh JG. 2019b. Die verband tussen broelingmassa en eiervolume in die Nylkrokodil (Crocodylus niloticus): Eiers se produktiwiteit varieer, Suid-Afrikaanse Tydskrif vir Natuurwetenskap en Tegnologie 38(1). English and Afrikaans versions of the manuscript available online at satnt. co.za/index.php/satnt/article/view/719.

Rassmann K, Schlötterer C, Tautz D. 1991. Isolation of simple-sequence loci for use in polymerase chain reaction-based DNA fingerprinting. Electrophoresis12, $113-118$.

Schlötterer C, Tautz D, 1992. Slippage synthesis of simple sequence DNA. Nucleic Acids Research, Vol. 20 (2), 211-215.

Sefc KM, Mattersdorfer K, Sturmbauer C, Koblmüller S. 2008. High frequency of multiple paternity in broods of a socially monogamous cichlid fish with biparental nest defence, Molecular Ecology 17, 2531-2543. DO 10.1111/j.1365-294X.2008.03763.x

Sefc KM, Koblmüller S. 2009. Assessing Parent Numbers from Offspring Genotypes: The Importance of Marker Polymorphism. Journal of Heredity 100(2):197205. DOI 10.1093/jhered/esn095.

Sugg DW, Chesser RK. 1994. Effective population sizes with multiple paternity. Genetics 137, 1147-1155.

Wang J. 2004. Sibship reconstruction from genetic data with typing errors. Genetics 166, 1963-1979.

Wang J. 2007. Parentage and sibship exclusions: higher statistical power with more family members. Heredity $99,205-217$.

Wang J. 2012. Computationally efficient sibship and parentage assignment from multilocus marker data. Genetics, 191, 183-194. DOI: 10.1534/ genetics.111.138149. 